\title{
Witold Mańczak (1924-2016) \\ Dorobek Profesora Mańczaka na tle paradygmatów lingwistycznych
}

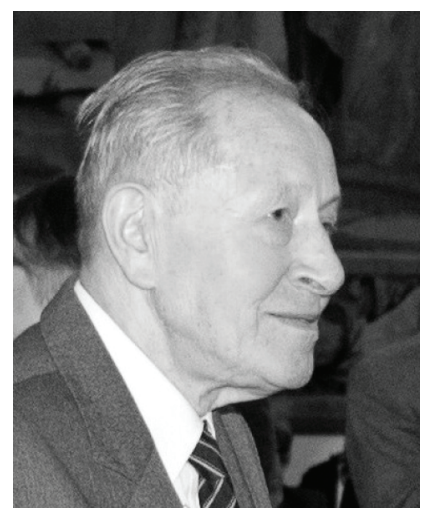

12 stycznia 2016 r. w Krakowie zmarł Witold Mańczak, światowego formatu indoeuropeista, romanista, slawista, teoretyk języka przez lata związany naukowo z Uniwersytetem Jagiellońskim. Urodzony 12 sierpnia 1924 r. w Sosnowcu, w 1936 roku rozpoczął naukę w sosnowieckim gimnazjum, w którym rozwijał fascynacje lingwistyczne, szczególną uwagą darząc podówczas język francuski i łacinę. Po ukończeniu trzech klas musiał przerwać naukę ze względu na wybuch II wojny światowej i wprowadzony przez okupanta zakaz kształcenia Polaków w szkołach średnich i uczelniach wyższych. W 1945 roku zdał maturę i podjął studia w Krakowie. Ukończył je szybko - w 1947 uzyskał dyplom Akademii Handlowej, w 1948 roku magisterium na romanistyce Uniwersytetu Jagiellońskiego, a w 1950 doktorat na tejże uczelni. Po studiach pracował jako urzędnik w firmie budowlanej, następnie był redaktorem w tygodniku Głos Anglii, a po jego zamknięciu urzędnikiem w Okręgowym Zarządzie Kin. Pracę na uczelni podjął w 1953 roku, na początek jako p.o. samodzielny 
pracownik nauki w Wyższej Szkole Pedagogicznej w Katowicach, a następnie w 1954 r. otrzymał etat zastępcy profesora w Katedrze Filologii Romańskiej Uniwersytetu Jagiellońskiego. W 1957 roku został docentem, po czym wyjechał po raz pierwszy do Francji, gdzie - jak sam napisał - odkrył, jakim cudem jest Bibliothèque nationale de France (Biblioteka Narodowa Francji), w której mógł odnaleźć wszystko, czego szukał (por. Mańczak 2014: 7). Podczas swojej kariery uniwersyteckiej zmagał się z wieloma przeciwnościami zewnętrznymi, uwarunkowanymi względami zarówno politycznymi, jak i naukowymi lub pozornie naukowymi. Profesorem nadzwyczajnym został w 1971 r., a zwyczajnym w roku 1982. W roku 1994 przeszedł na emeryturę, lecz jeszcze przez kilka lat pracował w Instytucie Filologii Romańskiej UJ w niepełnym wymiarze godzin. Był członkiem czynnym Polskiej Akademii Umiejętności, członkiem honorowym Polskiego Towarzystwa Językoznawczego i Komitetu Językoznawstwa PAN, członkiem Linguistic Association of Canada and the United States, należał do polskich i kilku zagranicznych towarzystw naukowych.

Profesor Mańczak był uznanym wykładowca, o czym m.in. świadczą liczne zaproszenia na wykłady gościnne do wielu ośrodków naukowych w Polsce i zagranicą. Jego studenci cenili zarówno jasny przekaz wykładów, jak i wprowadzane do nich dygresje z różnych obszarów lingwistyki. Utrzymywał kontakty naukowe z najważniejszymi lingwistami XX i XXI w., w czym niewątpliwe pomagała jego doskonała znajomość wielu języków, poza francuskim i innymi językami romańskimi, biegle posługiwał się niemieckim, angielskim, rosyjskim. Jego dorobek naukowy ma imponujący charakter. Opublikował 24 książki i ponad 960 innych tekstów w różnych językach i w różnych krajach, wiele jego artykułów naukowych ukazało się w wydawanych w Polsce i zagranicą księgach pamiątkowych dedykowanych najpoważniejszym lingwistom. Zajmował się zarówno językoznawstwem historycznym i porównawczym, jak i opisowym. Styl jego wypowiedzi naukowych był bardzo elegancki, wyrafinowany i nieskazitelnie logiczny. Do końca swoich dni pracował nad nowym, uwzględniającym sformułowaną przez siebie teorię nieregularnego rozwoju fonetycznego spowodowanego frekwencją, słownikiem etymologicznym języka polskiego (ukończone tuż przed Bożym Narodzeniem 2015 r. (w ostatnich dniach życia) dzieło zredagowali Leszek Bednarczuk i Mariola Jakubowicz; druk Polskiego słownika etymologicznego Witolda Mańczaka Wydawnictwo PAU zapowiedziało na 
wrzesień 2017 roku). Bez wątpienia odszedł od nas Profesor, uczony wybitny, wszechstronny i wspaniały człowiek o ogromnej erudycji, badacz obdarzony niespożytą pasją poznawczą, którego dorobek cechuje bogactwo wiedzy językoznawczej o ogromnym zasięgu tematycznym.

Największy wpływ naukowy wywarł na Profesora Mańczaka matematyk, wuj jego żony, prof. Hugo Steinhaus, współtwórca lwowskiej szkoły matematycznej, który uniknął mordu profesorów lwowskich w 1941 roku, a po wojnie pracował na Uniwersytecie Wrocławskim. Dzięki niemu Witold Mańczak zrozumiał, jak ogromna przepaść dzieli językoznawstwo i nauki ścisłe pod względem weryfikowalności twierdzeń. Zdaniem Mańczaka jednym z podstawowych problemów opisu lingwistycznego jest brak obiektywnych, naukowych kryteriów prawdy. Dylematy prawdziwościowe w językoznawstwie zazwyczaj rozwiązywane są na podstawie kryteriów opartych na autorytecie lub rzekomym autorytecie oraz - co niestety nierzadkie - przemilczaniu jednych poglądów i eksponowaniu innych (por. m.in. Mańczak 2010a: 25-26; 2013: 260).

Witold Mańczak w celu weryfikacji hipotez lingwistycznych stosował przede wszystkim metody statystyczne - statystyka w jego koncepcji pośredniczyła między sumą możliwych do zaobserwowania faktów lingwistycznych a ich interpretacją. Tylko te hipotezy i prawa językowe są prawidłowe, zdaniem Profesora, które dają się zweryfikować na bazie metody statystycznej i matematycznej. Uznał on już w początkach swojej drogi naukowej, że we wszystkich językach rozwój fonetyczny zależy od trzech głównych czynników: rozwoju regularnego, analogicznego oraz nieregularnego, skorelowanego z frekwencją użycia danej formy. W opinii prof. Zbigniewa Szkutnika, statystyka matematycznego i probabilisty, szansa nieprawdziwości teorii Mańczaka jest mniejsza niż 1 do 10 milionów (por. Mańczak 2011: 193-194). Językoznawstwo było dla niego nauką indukcyjną, wymagająca obserwacji faktów językowych, nie zaś konstruowania „papierowych” schematów czy systemów. Na podstawie danych wydobywanych z tekstów i ich frekwencji Witold Mańczak wnioskował na temat natury języka, konsekwentnie budował teorię, nie odrywając wzroku nawet od najmniejszych przejawów życia języka.

W sprzeczności z danymi statystycznymi stoją według Witolda Mańczaka teza Bartoliego, koncepcja cases vides (scil. ang. gaps) 'pustych przegródek' w systemie fonologicznym i teoria laryngalnych. Natomiast kilka innych 
hipotez, nierzadko uznawanych za prawa językowe, wymaga - w świetle danych płynących z obserwacji statystycznych - weryfikacji.

Matteo Bartoli, autor teorii neolingwistycznej, sformułował kilka norm, spośród których dwie najważniejsze głoszą, że w izolowanym obszarze językowym zachowa się więcej archaizmów niż w obszarze nieizolowanym, ponadto peryferie danego obszaru językowego są bardziej archaiczne niż jego centrum (Bartoli 1925: 3-9). Pierwszej z nich nie sposób według Mańczaka traktować jako odkrycia Bartoliego, ponieważ znana była ona językoznawcom od dawna: „Quant à la première « norme », il était depuis longtemps évident pour les linguistes que les parlers des régions « moins exposées aux communications », comme les îles, les montagnes, etc., ont un caractère archaïque, de sorte qu'il est impossible d'affirmer que Bartoli, formulant ce principe, ait découvert quelque chose de nouveau" (Mańczak 1965: 177-178) [Co do pierwszej „normy”, to dla językoznawców od dawna było oczywiste, że gwary regionów „trudno dostępnych”, takich jak wyspy, góry itp. mają charakter archaiczny, więc nie można twierdzić, że Bartoli, formułując tę zasadę, odkrył coś nowego]. Druga natomiast, nie znajduje potwierdzenia w zgromadzonym na podstawie słownika Bucka (1949) materiale empirycznym, którego analiza statystyczna pokazuje m.in. to, że w rumuńskim, peryferycznym spośród języków romańskich, zachowało się znacznie mniej archaizmów łacińskich niż np. we francuskim czy włoskim (języki centralne dla romańskiego obszaru językowego). Zdaniem Mańczaka nie ma żadnego związku między centralnym lub peryferycznym położeniem języka a stopniem jego archaiczności (por. Mańczak 1965: 183). Niemniej jednak - co jest ważnym rysem Profesora - jego krytyka nie miała charakteru wyłącznie negatywnego. Witold Mańczak w miejsce zakwestionowanej przez siebie „normy” Bartoliego wprowadza własną, opartą na rachunku prawdopodobieństwa: ,jeśli zjawisko B występuje na jednym obszarze, a zjawisko A na więcej niż jednym obszarze, to na ogół zjawisko A jest starsze od B, przy czym prawdopodobieństwo, że zjawisko A jest archaizmem, jest tym większe, im większa jest ilość obszarów, na których A jest zaświadczone" (Mańczak 1970: 238).

Profesor Mańczak był obdarzony wyczulonym słuchem etycznym, cechowała go uczciwość naukowa tak względem przedmiotu badań, jak i literatury mu poświęconej. Ten rys osobowości Profesora uwidacznia się m.in. na przykładzie krytyki cases vides (por. Mańczak 1970: 166-170; 1996a: 117-120). 
Po raz pierwszy zajął się tym problemem pod koniec lat 60. (por. np. Mańczak 1969), choć wracał do tego zagadnienia kilkakrotnie - jedna z jego ostatnich wypowiedzi na ten temat pochodzi z 2010 roku (Mańczak 2010b). W pierwszym ujęciu przywołuje pojęcie cases vides jako zoperacjonalizowane przez Andre Martineta (por. Martinet 1955: 80 nn.), jednak sprawdziwszy, że Martinet zapożyczył termin od Antoine'a Meilleta (Meillet 1925: 99), u którego pojawia się on tylko jeden raz i mam wątpliwości, czy istotnie jako termin, z ostrożnością weryfikował również własne sądy: „Nie wiem, czy Meillet był pierwszym, który użył terminu case vide, natomiast istotne jest to, że wśród językoznawców panuje powszechna zgoda co do tego, że we wszystkich językach przejawia się tendencja do wypełniania luk w «systemach fonologicznych»” (Mańczak 1996a: 117; 2010a: 36). Pojęcie „,pustej przegródki” (case vide) systemu fonologicznego służy do objaśniania rozwoju fonetycznego jako wypełniania luk w systemach fonologicznych. W myśl tej koncepcji brak symetrii w języku jest zjawiskiem nienaturalnym i jest on eliminowany za pomocą atrakcji przez zintegrowany system (l'attraction exercée par le système intégré), np. siedemnastowieczna zmiana w języku kastylijskim historycznej głoski ts na $\theta$ (jak w przykładzie cazar 'polować, por. [katsar] $\rightarrow[k a \theta a r]$ ) wypełnia lukę w szeregu $\mathrm{T}$, która się pojawiła ze względu na podobieństwo $t s$, do $t$, por. wsp. hiszp. fecha 'data'. Według Martineta system „cierpiał” ze względu na koncentrację dźwięków w tym szeregu („,ce système souffre de trop de concentration dans le domaine des sifflantes"), mimo że istniały inne niewykorzystywane możliwości artykulacyjne. W nowym systemie zaś fonemy są wyraźnie od siebie odróżnialne. Zdaniem W. Mańczaka rozwój fonetyczny nie ma charakteru symetrycznego, lecz asymetryczny, a częściej używane elementy językowe są bardziej zróżnicowane niż elementy rzadziej używane. Dla przykładu rozwój prasłowiańskich $*_{k},{ }^{*} g,{ }^{*} t$, *gj doprowadził w niektórych systemach słowiańskich nie tyle do wypełnienia luki, ile do powstania cases vides w wyniku zaniku 3 oraz $\breve{3}$. Tendencja do asymetrii w obrębie systemów fonologicznych języków słowiańskich jest znacznie większa niż tendencja do symetrii. Symetrycznością odznaczają się w tych wypadkach właściwie jedynie szeregi syczące i szumiące, podczas gdy pozostałe należy uznać za asymetryczne. Według Profesora „languages do not show a kind of horror vacui; not symmetry, but asymmetry is a characteristic feature of every language. It is possible to formulate the following law concerning the relation between frequency and differentiation of linguistic 
elements: the linguistic elements more frequently used are, in general, more differentiated than those less frequently used" (Mańczak 2010b: 135) [języki nie wykazują czegoś w rodzaju horror vacui; nie tyle symetria, ile asymetria jest cechą charakterystyczną każdego języka. Można zatem sformułować następujące prawo dotyczące relacji między frekwencją a zróżnicowaniem elementów języka: elementy języka częściej używane są na ogół bardziej zróżnicowane niż elementy rzadziej używane].

Sformułowana na podstawie hipotezy Ferdynanda de Saussure’a (1879) i odkryć Jerzego Kuryłowicza (1927a, b) teoria laryngalnych nie znajduje zdaniem Witolda Mańczaka (1995, 2004a) potwierdzenia w danych statystycznych (kiedy Profesor dowiedział się, że planuję przekład wczesnej pracy de Saussure'a pt. Mémoire sur le système primitif des voyelles dans les langues indo-européennes, wysłał do mnie list, w którym m.in. napisał: „ta praca Saussure'a nie zasługuje na przekład, gdyż ona stanowi punkt wyjścia teorii laryngalnej, a ta jest błędna”). Klasyczną metodą historyczno-porównawczą możemy odtworzyć z dość dużym prawdopodobieństwem stan późno-indo-europejski w momencie rozpadu prajęzyka, natomiast jego wcześniejsza ewolucja i wczesno-indo-europejski system fonologiczny jest od dawna przedmiotem hipotez opartych na zakładanym pokrewieństwie z innymi rodzinami językowymi i/lub na rekonstrukcji wewnętrznej. Młodogramatycy rekonstruowali indoeuropejski system wokaliczny jako taki, który zawiera samogłoski krótkie, długie, dyftongi, głoski zredukowane a oraz $b$ (według Hirta), sonanty krótkie i długie $(i, u)$ oraz zgłoskotwórcze płynne i nosowe $(r, l, m, n)$, które m.in. zdaniem Hirta nie bywają długimi (Brugmann różnicuje ten typ sonantów na długie i krótkie). W tym systemie zredukowane szwa jest stopniem redukcji samogłoski długiej i odpowiada wed. $i$, a w językach zachodnich $-a$, stąd wed. pitā, goc. fadar $\leftarrow$ pie. * pətêr 'ojciec'. De Saussure wskazał, że dwa typy wymiany samogłosek w językach indoeuropejskich moga być sprowadzone do jednego, co pozwala za zbyteczne postulowanie samogłosek długich. Opozycja $\bar{a}$ : ə jest proporcjonalna do $e i: i$, stąd $\bar{a}$ można przedstawić jako $e+$,koeficjent sonantyczny” analogiczny do $i, u, r, l, m, n$ w tych wypadkach, w których stanowi on drugi komponent połączeń dyftongicznych. Z proporcji $\bar{a}: \partial=e i: i$ wynika, że $\bar{a}:$ a można przekodować jako $e A: A=e i: i$ z dalszym rozwojem $e A>\bar{a}$, $A>\partial$. W wypadku $\bar{o}:$ d de Saussure postulował $e Q: Q$ oraz $e Q>\bar{o} i Q>\partial$. Proponował on zatem przyjęcie hipotetycznego elementu, który oznaczał 
jako $A$, oraz rozkład długich samogłosek na odpowiednie samogłoski krótkie $+A$. To pozwoliło mu uzyskać ścisłe analogie między szeregami apofonicznymi, wcześniej uznawanymi za zupełnie różnorodne. Element $A$ był dla de Saussure'a jedynie postulatem, jednostką abstrakcyjną, czysto formalną, o niewiadomej realizacji substancjalnej. Po jego śmierci ów typ dźwięku scharakteryzowano $\mathrm{w}$ przybliżeniu na postawie odnalezionych zabytków hetyckich. Trzeciego koeficjenta sonantycznego $(\bar{e}: \curvearrowright<e E: E)$ de Saussure nie wprowadził, ale po kilku latach Hermann Møller (Möller 1917) w próbie zbliżenia języków indoeuropejskich $i$ chamito-semickich przedstawił system trzech laryngalnych (termin laryngalne zapożyczył Møller z semitologii). Klasyczną postać tej teorii nadał Jerzy Kuryłowicz, odkrywszy w języku hetyckim spółgłoskowe odpowiedniki Saussure'owskich koeficjentów sonantycznych. Kuryłowicz zaproponował przyjęcie dla języka indoeuropejskiego czterech szwa spółgłoskowych, z których między innymi wyprowadza się wokalizm języków indoeuropejskich. Zdaniem Witolda Mańczaka odkrycie genezy przemian morfologicznych na podstawie danych opisowych pochodzących z jednego tylko języka jest bardzo trudne lub wręcz niemożliwe. Rekonstrukcja wewnętrzna w takich wypadkach jest mocno ograniczona. Gdybyśmy wzięli pod uwagę trzy szeregi: ręka : rękę : ręce : ręczny; noga : noge : nodze : nożny oraz woda : wode : wodzie : wodny, to - w myśl hipotezy de Saussure’a - alternujące ze sobą spółgłoski można by było rozłożyć na spółgłoski twarde i trzy koeficjenty palatalne $X, Y, Z$ : koeficjent $X$ odpowiadałby za miękkość, por. ręce $\leftarrow{ }^{*}$ rękXe, nodze $\leftarrow{ }^{*}$ nogXe, wodzie $\leftarrow{ }^{*}$ wodXe, koeficjent $Y$ byłby przyczyną palatlizacji w ręczny, nożny (por. rękYny), natomiast koeficjent $Z$ zanikłby bez śladu, jak w przykładzie *wodZny $\rightarrow$ wodny. $\mathrm{W}$ istocie $\mathrm{w}$ językach słowiańskich takie koeficjenty nie istniały, a zmiany w podanych przykładach są efektem m.in. I palatalizacji (ręczny, nożny), II palatalizacji (ręce, nodze), tzw. palatalizacji polskiej (wodzie), dyspalatalizacji $d$ pod wpływem $n$ (wodny). Odkrycie wskazanych alternacji metodą rekonstrukcji wewnętrznych jest niemożliwe, a wyjaśnianie ich za pomocą koeficjentów sonantycznych fałszywe. De Saussure postulował, jak to zostało powiedziane wyżej, rozkład odpowiednich dźwięków na $* e+$ koeficjent, co sugeruje, że zakładał on istnienie w systemie wczesno-indo-europejskim wyłącznie jednej samogłoski. Oswald Szemerényi (Szemerényi 1996: 137), którego wypowiedź przytacza Profesor Mańczak, uważa, że należy odrzucić teorię laryngalną w jej wersji z jedną tylko 
samogłoską, ponieważ nie ma żadnego takiego języka z jedną samogłoską. Witold Mańczak wykazał ponadto nieścisłości w propozycjach Møllera i Kuryłowicza oraz ich kontynuatorów, które jego zdaniem wskazują na inne wady teorii laryngalnych, chodzi tu m.in. o niepewność danych hetyckich, różną ilość i naturę głosek laryngalnych oraz zmianę postulowanych spółgłosek krtaniowych w indoeuropejskie samogłoski, podczas gdy w innych językach spółgłoski ewoluują zazwyczaj w spółgłoski, nie zaś w samogłoski.

Trzeba było wykazać się nie lada odwagą, aby w środowisku językoznawczym, w którym w latach 50. i 60. przebywał Profesor Mańczak, otwarcie krytykować de Saussure’a i zapoczątkowaną przez niego metodę. Nie chodziło bowiem wyłącznie o teorię laryngalnych, lecz przede wszystkim o doktrynę de Saussure'a i Kurs językoznawstwa ogólnego, o którym Witold Mańczak pisał: ,„przeczytałem go z zachwytem. [...] do Kursu wracałem nieraz. Za każdym jednak razem mój zachwyt nad książką Saussure’a malał, aż wreszcie uświadomiłem sobie, że Kurs językoznawstwa ogólnego obfituje $\mathrm{z}$ jednej strony w twierdzenia prawdziwe, ale nieoryginalne, a z drugiej w twierdzenia oryginalne, ale nieprawdziwe" (Mańczak 1970: 16). Profesor kwestionował przede wszystkim Saussure'owską definicję języka, uznając, że językiem jest to wszystko, co się mówi lub pisze, i dualistyczny charakter doktryny Genewczyka na rzecz monistycznej koncepcji języka z różnicami ilościowymi, a nie jakościowymi.

W ocenie Witolda Mańczaka rewizji wymaga prawo Vernera (por. Verner 1877), które - najogólniej rzecz ujmując - głosi, że bezdźwięczne głoski frykatywne w języku pragermańskim ${ }^{*} f,{ }^{*} p,{ }^{*} s,{ }^{*} \chi,{ }^{*} \chi^{w}$ (odpowiedniki pie. ${ }^{*} p,{ }^{*} t$, $\left.*_{s}, *_{l}, *^{w}\right)$, jeśli występowały bezpośrednio po poprzedzającej je nieakcentowanej sylabie w tym samym słowie, przechodziły w dźwięczne głoski frykatywne, odpowiednio: ${ }^{*} \beta,{ }^{*} \partial,{ }^{*},{ }^{*}{ }^{\gamma},{ }^{*} \gamma^{w}$, w rodzaju ásasa $\rightarrow$ ásaz(a), asása $\rightarrow$ azás(a), por. goc. sibun i skr. sāpta- 'siedem', stang. foeder czy stnord. faðir

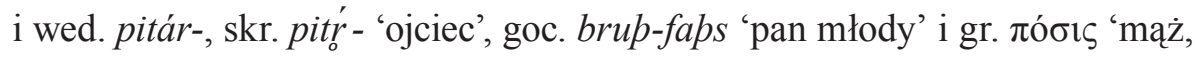
małżonek' itd. Korekta, którą zaproponował Mańczak, wiąże się z zasięgiem oddziaływania wymiany głoskowej. Mańczak (1990, 1996b) po przeanalizowaniu przykładów gockich, zachodniogermańskich i skandynawskich oraz zestawieniu ich z hetyckimi, tocharskimi, sanskryckimi, awestyjskimi, starosłowiańskimi, litewskimi, ormiańskimi, greckimi, łacińskimi i irlandzkimi, doszedł do przekonania, że prawo Vernera zachodzi jedynie w śródgłosie i że 
końcowe praindoeuropejskie *-s nie ewoluowało na gruncie zarówno pragermańskim, jak i gockim w myśl prawa Vernera. Tezę tę wspiera pięć argumentów: w pragermańskim końcowe ${ }^{*} s$ przechodziło $\mathrm{w} * z$ również w wyrażeniach akcentowanych (po sylabie akcentowanej) w rodzaju *ul $k_{0}^{u} O S \rightarrow$ *wulhwaz; następnie uległo ono w pragermańskim zmianom analogicznym, pod wpływem * $*_{-z}$ w słowach akcentowanych typu *bhosós 'goły' (pgerm. *bazaz) - w prawie wszystkich podręcznikach do językoznawstwa germańskiego formy pragermańskie są zazwyczaj przytaczane z zakończeniem *-z; w gockim * $*_{-z}$ przekształcało się $\mathrm{w}-s$; w tzw. językach zachodniogermańskich $*_{-z}$ zanikało; w językach skandynawskich $*_{-z}$ jest kontynuowane jako $-r$.

W tym miejscu należy poczynić ważną uwagę. Witold Mańczak odróżniał w swoich badaniach pokrewieństwo językowe, o którym decydują odpowiedniości fonetyczne, od stopnia pokrewieństwa językowego, o którym decydują podobieństwa leksykalne. Przeczył sformułowanej w XVII w. przez niemieckiego orientalistę i filologa Hioba Ludolfa, a powtórzonej przez Hugo Schuchardta (Schuchardt 1928: 198) tezie, jakoby na relacje między językami wskazywał nie słownik, lecz gramatyka. Wbrew temu poglądowi Profesor przekonywająco dowodził, że o stopniu pokrewieństwa językowego decydują zbieżności słownikowe, a nie zbieżności fonetyczne i fleksyjne. Dla przykładu to, że łacina jest spokrewniona bliżej z francuskim niż z gockim, że gocki jest bliżej spokrewniony $\mathrm{z}$ angielskim niż ze staro-cerkiewno-słowiańskim oraz że polski jest spokrewniony bliżej z bułgarskim niż z litewskim, opiera się na podobieństwach nie fleksyjnych, ale leksykalnych. Gdyby z kolei wziąć pod uwagę podobieństwa fleksyjne, okazałoby się na przykład, że gocki jest bliżej spokrewniony ze staro-cerkiewno-słowiańskim, aniżeli z angielskim (por. Mańczak 1999: 84-85), a łacina z gockim niż z francuskim (por. Mańczak 1991b: 15-16). Natomiast jeśli weźmie się pod uwagę cechy fonetyczne, to okaże się, że np. język polski jest bliżej spokrewniony z rosyjskim niż z ukraińskim, choć w istocie jest odwrotnie (por. Mańczak 2009: 14).

Metoda określania stopnia podobieństwa językowego za pomocą badania i porównywania leksyki najczęściej w paralelnych tekstach posłużyła Witoldowi Mańczakowi m.in. do zaproponowania nowych rozwiązań problemów związanych z etnogenezą Indoeuropejczyków, Gotów i Słowian. Doszedł on do wniosku, że wbrew szerzącym się w średniowieczu przekonaniom praojczyzna Gotów leżała nie w Skandynawii, ale w najbardziej południowej części starożytnej Germanii, a co za tym idzie współcześnie stosowany podział 
na języki wschodnio-, zachodniogermańskie i skandynawskie ma charakter wyłącznie umowny. Gocki wykazuje bowiem najwięcej podobieństw leksykalnych do wysokoniemieckiego, a najmniej do języków skandynawskich. Ponadto udowodnił, że w świetle danych statystycznych oryginalne siedlisko Indoeuropejczyków pokrywa się z siedliskiem Słowian, to znaczy znajdowało się ono w dorzeczu Odry i Wisły, między plemionami germańskimi a bałtyckimi; te ostatnie ukształtowały się w wyniku migracji na północ i zetknięcia się z ludami ugrofińskimi (por. Mańczak 1999: 89-144). Przy okazji nakreślił hipotetyczną drogę migracji ludów indoeuropejskich z ich pierwotnych siedzib (głównie przez Bałkany i Azję Mniejszą, która stanowiła pomost łączący Indoeuropejczyków europejskich z azjatyckimi) oraz akulturacji ludów, które Indoeuropejczycy asymilowali podczas swoich wędrówek - indoeuropeizacja następowała stopniowo poprzez przejmowanie przez daną ludność miejscową języka indoeuropejskich przybyszy. W ten mniej więcej sposób, a nie w wyniku podbojów czy masowej ekspansji, musiała przesuwać się fala migracyjna języków indoeuropejskich.

W świetle danych statystycznych język staro-cerkiewno-słowiański należy uznać za kompromis między dialektem macedońsko-bułgarskim (teza głoszona przez większość slawistów) a narzeczem morawsko-panońskim (postulat Jerneja Kopitara i Franca Miklošiča), por. Mańczak (2004b, 2006, 2012). Podobieństwa leksykalne między językiem staro-cerkiewno-słowiańskim a innymi językami słowiańskimi wskazują, że nawiązań leksykalnych do języka staro-cerkiewno-słowiańskiego najwięcej jest w serbsko-chorwackim, mniej w słoweńskim, a jeszcze mniej w macedońskim i bułgarskim. „Gdyby język staro-cerkiewno-słowiański - pisze Mańczak (2012: 64) - powstał na obszarze morawsko-panońskim, [...] [to] musiałby wykazywać najwięcej nawiązań leksykalnych do słoweńskiego. Gdyby język staro-cerkiewno-słowiański zrodził się na obszarze macedońsko-bułgarskim, [...] to by musiał wykazywać najwięcej zbieżności z macedońskim i bułgarskim. Tymczasem w rzeczywistości pod względem leksykalnym staro-cerkiewno-słowiański nawiązuje najbardziej do serbochorwackiego, który stanowi ogniwo pośrednie między słoweńskim a macedońskim i bułgarskim. Z tego wniosek, że język staro-cerkiewno-słowiański stanowi kompromis między dialektem macedońsko-bułgarskim a narzeczem morawsko-panońskim. Konstantyn i Metody tłumaczyli z greki na znany sobie dialekt macedońsko-bułgarski, ale następnie częściowo modyfikowali swe przekłady, by były bardziej zrozumiałe dla 
ludności mówiącej narzeczem morawsko-panońskim”. Teza ta w zasadniczy sposób zmienia optykę widzenia stosunków językowych w obrębie południowej słowiańszczyzny i relacji między pierwszym zapisanym językiem słowiańskim a wpływami na niego leksyki religijnej zapożyczanej z misji salzburskiej. Wydaje się, że zapożyczenia łacińsko-niemieckie nie odgrywały tak doniosłej roli w kształtowaniu się języka staro-cerkiewno-słowiańskiego i jego redakcji, jak sądzono przed badaniami Profesora Mańczaka.

Metoda zastosowana do języka staro-cerkiewno-słowiańskiego, uprzednio była testowana na językach romańskich (Mańczak 1974, 1991b, 2010c). Od XV w. panuje przekonanie, że języki romańskie wywodzą się z analitycznej łaciny ludowej, używanej w starożytności obok łaciny klasycznej jako jej „plebejski” wariant; współcześnie jego zwolennikiem jest m.in. Coşeriu (1954: 29), którego zdaniem z łaciny archaicznej wytworzyły się dwie odmiany języka łacińskiego: literacka i ludowa lub popularna, a z tej ostatniej języki romańskie. Witold Mańczak, nie podzielał jednak tego poglądu, opowiadał się za tezą głoszoną przez Franza Eyssenhardta (1882: 127-128) oraz Henri Mullera i Pauline Taylor (por. Muller i Taylor 1932: IV), według której ,języki romańskie powstały z łaciny klasycznej, a łacina ludowa, zróżnicowana w czasie i przestrzeni, stanowiła jedynie ogniwo pośrednie między łaciną klasyczną a najstarszymi zabytkami języków romańskich" (Mańczak 1999: 46), za czym przemawiają przykłady w rodzaju: łac. klas. coelum $\rightarrow$ łac. lud. *celu (postać rekonstruowana z zanikiem końcowego -m) $\rightarrow$ fr. ciel 'niebo'.

Kolejnym zagadnieniem z zakresu językoznawstwa ogólnego, którym zajął się Witold Mańczak, jest podział leksyki na wyrazy akcentowane i nieakcentowane (Mańczak 1952a, b, c, 1991a; 1996a: 77-80). Wśród tych ostatnich wymienia się zazwyczaj zaimki, rodzajniki, przyimki, spójniki. Zdaniem Profesora jest to fałszywe uogólnienie. Rzecz w tym, że klityki zachowują się tak samo, jak nieakcentowane sylaby wyrażeń wielosylabowych, por. dix vers 'dziesięć' i divers 'różnorodny' lub wy lećcie i wylećcie. W grupach dwuwyrazowych nie da się wymawiać obu słów z tą samą siłą, co nie znaczy, że jeden z tych wyrazów pozbawiony jest zupełnie akcentu. Tradycyjne rozróżnianie wyrażeń nieakcentowanych i akcentowanych winno być poddane rewizji.

Witold Mańczak zaproponował również przyjęcie definicji nazw własnych jako takich, które zasadniczo różnią się od apelatywów ich 
nieprzekładalnością z języka na język (np. Warschau, Varsovie, Warsaw to nie tłumaczenia nazwy Warszawa, lecz jej adaptacje fonetyczne, podobnie jak nazwy Paryż, Parigi itd. są adaptacjami francuskiej nazwy Paris). Tym samym przeciwstawił się tradycyjnemu podejściu do tych wyrażeń jako do nazw o charakterze indywidualnym, o jednostkowym desygnacie. Twierdził bowiem, że każde imię, każde nazwisko, każda nazwa mieszkańca itd. oznaczają nie pojedyncze indywidua, ale wiele obiektów, por. np. Paris (nazwa miasta w Teksasie) czy Warsaw (nazwa miasta w Indianie).

Profesor był autorem gramatyk opisowych lub historycznych francuskiego, włoskiego, hiszpańskiego oraz kilkakrotnie wznawianego podręcznika z fonetyki i morfologii historycznej języka polskiego (por. Mańczak 1983). Zaproponował wiele etymologii, często wyrażeń, dla których ustalenie pochodzenia nastręczało rozmaitych trudności innym etymologom. Wykazał m.in., że fr. aller, wł. andare, hiszp. andar, oksyt. anar itd. wywodzą się $\mathrm{z}$ jednego etymonu, od czasownika łacińskiego ambulo, ambulāre 'iść pieszo'. Objaśnił za pomocą rozwijanej przez siebie teorii etymologie zaś (z zasie, a to z kolei z zasię), dla z psł. *děl'a, nieregularne redukcje w *jazъ, *jbgra itd. Etymologie wyrażeń polskich weszły do Polskiego słownika etymologicznego, który zawiera także wiele przykładów etymologii wyrazów obcych, służących Profesorowi jako egzemplifikacja głoszonych przez niego rozwiązań etymologicznych. Metoda etymologiczna Mańczaka miała charakter semantyczno-fonetyczny; w konstruowaniu hipotez etymologicznych poszukiwał on bowiem zarówno odpowiedniości fonetycznych, jak i znaczeniowych, za każdym razem ustalając stopień ich prawdopodobieństwa.

Był także Witold Mańczak uważnym recenzentem. Zrecenzował blisko 200 tekstów z różnych poddziedzin językoznawstwa, zarówno polskich, jak i obcych autorów. Czytał bardzo dużo, a wiele jego lektur pozostawiło ślad w jego własnych pracach naukowych. Był uczonym o nieposkromionej pasji poznawczej. Jego znajomość literatury przedmiotu była imponująca, co się ujawnia przy lekturze jego tekstów. Erudycja Profesora onieśmiela czytelnika, a jednocześnie pobudza do samodzielnych poszukiwań prawdy tak, by znalazłszy ją, nie ustawać w jej poszukiwaniu.

Dla wielu Profesor pozostanie w pamięci jako niestrudzony polemista. Dyskusje, które prowadził ze swoim nauczycielem, a jednocześnie jednym z najważniejszych antagonistów, Jerzym Kuryłowiczem, wpłynęły w moim przekonaniu zasadniczo na tworzoną przez Profesora teorię 
języka. Kuryłowicz (1945-1949) sformułował sześć praw rozwoju morfologicznego: (1) morfem dwustronny przejmuje funkcję morfemu prostego izofunkcyjnego, to znaczy morfem złożony zastępuje morfem prosty; (2) kierunek działań analogicznych jest od formy fundacji (wyjściowej) do formy ufundowanej; (3) struktura złożona z członu konstytutywnego i elementów zawierających większą liczbę elementów podporządkowanych tworzy fundację w stosunku do elementu składowego izolowanego, choć izofunkcyjnego; (4) w wyniku derywacji morfologicznej forma ulega zróżnicowaniu, nowa, derywowana forma przejmuje funkcję podstawową, natomiast dawna forma pełni funkcję sekundarną (fundowaną); (5) różnica, która ma charakter centralny, może być przywrócona kosztem tej, która ma charakter bardziej marginalny; (6) pierwszy i drugi człon proporcji należą pierwotnie do różnych systemów: pierwszy należy do mowy imitowanej (imité), drugi - imitującej (imitant). Autor na podstawie tych praw napisał rozprawy o akcentuacji i apofonii w językach indoeuropejskich (por. Kuryłowicz 1952, 1956). Zdaniem Mańczaka (1957-1958) prawa te nie tylko są dość hermetycznie sformułowane (zawierają wiele neologizmów), lecz co istotniejsze, opierają się na niewielkiej liczbie przykładów i nie wytrzymują konfrontacji z większą ilością faktów materiałowych. Profesor w miejsce sześciu praw Kuryłowicza zaproponował pięć własnych hipotez-praw: (1) wyrazy dłuższe zazwyczaj są przekształcane na wzór krótszych, a nie odwrotnie; (2) alternacja tematu jest częściej usuwana niż wprowadzana; (3) forma fleksyjna dłuższa zazwyczaj jest przekształcana na wzór formy fleksyjnej krótszej; (4) końcówki zerowe są częściej zastępowane przez końcówki pełne; (5) końcówki monosylabiczne są częściej zastępowane przez końcówki wielosylabowe. Kuryłowicz odpowiedział na ten artykuł w Biuletynie PTJ (Kuryłowicz 1958) tekstem na temat ogólnych tendencji zmian analogicznych, zarzucającym Profesorowi Mańczakowi powierzchowność, nieznajomość rzeczy i operowanie faktami izolowanymi, podczas gdy Kuryłowicz brał pod uwagę fakty kategorialne. Między oboma uczonymi doszło jeszcze tylko do jednej wymiany argumentów. Witold Mańczak napisał artykuł pt. Odpowiedź Prof. J. Kuryłowiczowi (por. Mańczak 1960), natomiast Jerzy Kuryłowicz tekst zatytułowany Odpowiedź jezzykoznawstwa (por. Kuryłowicz 1960). Kilkakrotnie jeszcze Profesor Mańczak powracał do zagadnienia praw rozwoju analogicznego (por. np. Mańczak 1978, 1980), formułując ostatecznie cztery oparte na statystyce prawa: (1) morfemów o tym samym znaczeniu 
częściej ubywa, niż przybywa, por. psł. dat. pl. *-omъ, *-emъ i *-amъ oraz pol. -om; (2) morfemy/wyrazy krótsze/wyrazy częściej są zastępowane przez morfemy/wyrazy dłuższe/grupy wyrazowe niż na odwrót, por. stpol. najdować i pol. znajdować; (3) morfemy/wyrazy krótsze/wyrazy częściej się zachowują niż morfemy/wyrazy dłuższe/grupy wyrazowe, a ponadto częściej zachowują charakter archaiczny i częściej powodują przekształcanie drugich, por. ins. pl. od stowo: stowami i stowy, podczas gdy ins. pl. od stówko to jedynie słówkami; (4) formy częściej używane zachowują się częściej niż formy rzadziej używane, np. przekształcanie imperatywu od czasownika jeździć z jeźdź na jeździj. Współczesna nauka „połączyła” obu wybitnych indoeuropeistów, a w pewnym sensie ich pogodziła. Bowiem indoeuropejskie prawo związane z procesami analogicznymi określane jest dziś w nauce mianem prawa Kuryłowicza-Mańczaka (por. Collinge 1985: 249-253).

Jak to pokazuje powyższy przegląd, Witold Mańczak był twórcą spójnej teorii opartej na jednolitym i metodycznym spojrzeniu na język za pomoca metod statystycznych służących mu do weryfikacji hipotez. Zrą̧ tej teorii powstał bardzo wcześnie, bo już na początku pracy naukowej Profesora. Jestem przekonany, że prace Profesora, również te drukowane w naszym piśmie, będą długo obecne $\mathrm{w}$ dorobku nauki jako swoisty przewodnik po języku, językach i metodzie. Lecz nade wszystko będą świadectwem postawy uczonego zorientowanego na prawdę i jej odkrywanie, nawet wbrew/pomimo i ,przeciwko smokom, jadom, kulom, grotom”.

Cześć Jego pamięci!

Piotr Sobotka

\section{Bibliografia}

Bartoli M., 1925, Introduzione alla neolinguistica (Principi - scopi - metodi), Genève: Leo S. Olschki.

Buck C.D., 1949, A dictionary of selected synonyms in the principal Indo-European languages. A contribution to the history of ideas, Chicago-London: The University of Chicago Press.

Collinge N.E., 1985, Laws of Indo-European, Amsterdam-Philadelphia: John Benjamins Publishing Company. 
COŞERIU E., 1954, El llamado «Latin vulgar» y las primeras diferenciaciones romances. Breve introducción a la lingüistica románica, Montevideo: Universidad de la República.

EysSENhaRdT F., 1882, Roemisch und romanisch. Ein beitrag zur sprachgeschichte, Berlin: Gebrüder Borntræger (E. Eggers).

KuryŁowicz J., 1927a, a indoeuropéen et hh hittite, w: Symbolae grammaticae in honorem Ioannis Rozwadowski, t. 1, Cracoviae: Gebethner \& Wolff, s. 95-104.

KuryŁowicz J., 1927b, Les effets du a en indoiranien, Prace Filologiczne 11, s. 201-243 .

KuryŁowicz J., 1945-1949, La nature des procés dits «Analogiques», Acta Linguistica 5(1), s. 15-37.

KuryŁowicz J., 1952, L'accentuation des langues indo-européennes, Kraków: Nakładem Polskiej Akademii Umiejętności.

KuryŁowicz J., 1956, L'apophonie en indo-européen, Wrocław: Zakład im. Ossolińskich.

KuryŁowicz J., 1958, Ogólne tendencje zmian analogicznych, Biuletyn Polskiego Towarzystwa Językoznawczego 17, s. 207-219.

KuryŁowicz J., 1960, Odpowiedź językoznawstwa, Biuletyn Polskiego Towarzystwa Językoznawczego 19, s. 203-210.

MańcZAK W., 1952a, Enklityki i proklityki, Język Polski 32, s. 66-76.

MAŃCZAK W., 1952b, O akcentuacji grup dwuwyrazowych, Język Polski 32, s. 15-24.

MAŃCZAK W., 1952c, O akcentuacji grup ponaddwuwyrazowych, Język Polski 32, s. $145-156$.

MAŃCZAK W., 1957-1958, Tendances générales des changements analogiques, Lingua 7, s. 298-325.

Mańczak W., 1960, Odpowiedź Prof. J. Kuryłowiczowi, Biuletyn Polskiego Towarzystwa Językoznawczego 19, s. 191-201.

MAŃCZAK W., 1965, La nature des archaïsmes des aires latérales, Lingua 13, s. 177-184.

MAŃCZAK W., 1969, Do the 'cases vides' exist?, Linguistica Antverpiensia 3, s. 295-303.

MAŃCZAK W., 1970, Z zagadnień językoznawstwa ogólnego, Wrocław-Warszawa-Kraków: Zakład Narodowy im. Ossolińskich.

MAŃCZAK W., 1974, La langue romane commune: latin vulgaire ou latin classique?, Revue Romane 9, s. 218-231.

MAŃCZAK W., 1978, Les lois du développement analogique, Linguistics 16(205), S. $53-60$.

MańCZAK W., 1980, Laws of analogy, w: J. Fisiak (red.), Historical Morphology, The Hague-Paris-New York: Mouton Publishers, s. 283-288.

MaŃCZAK W., 1983, Polska fonetyka i morfologia historyczna, Warszawa: Państwowe Wydawnictwo Naukowe. 
MAŃCZAK W., 1990, La restriction de la règle de Verner à la position médiane et le sort du s final en germanique, Historische Sprachforschung / Historical Linguistics 103(1), s. 92-101.

MAŃCZAK W., 1991a, La division des mots en toniques et atones est-elle justifiée?, Lingua Posnaniensis 32-33, s. 181-185.

MAŃCZAK W., 1991b, Nouvelle classification des langues romanes, Revue Romane 26(1), s. 15-23.

MańcZAK W., 1995, Critique de la théorie des laryngales, w: W. Smoczyński (red.), Analecta Indoeuropaea Cracoviensia Ioannis Safarewicz memoriae dicata, Kraków: Universitas, s. 237-247.

MańcZak W., 1996a, Problemy językoznawstwa ogólnego, Wrocław-Warszawa-Kraków: Zakład Narodowy im. Ossolińskich - Wydawnictwo.

MAŃCZAK W., 1996b, La règle de Verner s'applique-t-elle à la position finale?, Historische Sprachforschung / Historical Linguistics 109(1), s. 110-116.

MańCZAK W., 1999, Wieża Babel, Wrocław-Warszawa-Kraków: Zakład Narodowy im. Ossolińskich - Wydawnictwo.

MAŃCZAK W., 2004a, Encore un argument contre la théorie des laryngales, Lingua Posnaniensis 46, s. 41-44.

MańCZAK W., 2004b, Przedhistoryczne migracje Słowian i pochodzenie języka staro-cerkiewno-słowiańskiego, Kraków: Polska Akademia Umiejętności.

MańCZAK W., 2006, Pochodzenie języka staro-cerkiewno-słowiańskiego a Kodeks zografski, Warszawa: Wydawnictwo Takt.

MAŃCZAK W., 2009, O istocie pokrewieństwa językowego, w: A. Bochnakowa, L. Bednarczuk, J. Waniakowa (red.), Polszczyzna i inne języki. Materiaty z seminarium naukowego poświęconego pamięci doc. dr. hab. Józefa Reczka, Kraków: Wydawnictwo Uniwersytetu Jagiellońskiego, s. 13-19.

MAŃCZAK W., 2010a, Językoznawstwo oparte nie na wierze w nieomylność autorytetów, ale na statystyce, w: J. Wawrzyńczyk, D. Bralewski (red.), Ze wspomnień polskich językoznawców, t. 1, Łask: Oficyna Wydawnicza Leksem, s. 22-43.

MańCZAK W., 2010b, A note on cases vides, Folia Linguistica Historica 44 (Historica 31), s. 135-138.

MAŃCZAK W., 2010c, Le problème de l'origine des langues romanes dans le livre de H. Lüdtke et celui de R. Kiesler, w: M. Iliescu, H. Siller-Runggaldier, P. Danler (red.), XXVe CILPR Congrès International de Linguistique et de Philologie Romanes Innsbruck, 3-8 septembre 2007, t. 6, Berlin-New York: Walter de Gruyter, s. 207-211.

MAŃCZAK W., 2011, Etymologia przyimka dla a nieregularny rozwój fonetyczny spowodowany frekwencją, Prace Filologiczne 60, s. 189-195.

MańCZAK W., 2012, O pochodzeniu języka staro-cerkiewno-słowiańskiego, Rocznik Slawistyczny 56, s. 59-68. 
MańczaK W., 2013, Kazimierz Polański, Gramatyka języka połabskiego, www.sbc. org.pl/Content/18899/gramatyka_jezyka_polabskiego.pdf, Linguistica Copernicana 10(2), s. 257-261.

MańCZAK W., 2014, Vie et recherche de Witold Mańczak, w: L. Bednarczuk et al. (red.), Linguistique romane et linguistique indo-européenne. Mélanges offerts à Witold Mańczak à l'occasion de son 90e anniversaire, Kraków: Polska Akademia Umiejętności - Instytut Filologii Romańskiej UJ, s. 7-10.

Martinet A., 1955, Économie des changements phonétiques. Traité de phonologie diachronique, Berne: A. Francke.

Meillet A., 1925, La Méthode comparative en linguistique historique, Oslo: H. Aschehoug.

MöLleR H., 1917, Die semitisch-vorindogermanischen laryngalen konsonanten, København: A. F. Høst \& søn.

Muller H.F., TAylor P., 1932, A Chrestomathy of Vulgar Latin, Boston: D. C. Heath and company.

SAussure F. DE, 1879, Mémoire sur le système primitif des voyelles dans les langues indo-européennes, Leipsick: B. G. Teubner.

Schuchardt H., 1928, Hugo Schuchardt-Brevier. Ein Vademecum der allgemeinen Sprachwissenschaft, Halle (Saale): Max Niemeyer.

SzEMERÉNYi O., 1996, Introduction to Indo-European Linguistics. Translated from Einführung in die vergleichende Sprachwissenschaft 4th edition, 1990 with additional notes and references, Oxford: Oxford University Press.

VERNER K., 1877, Eine ausnahme der ersten lautverschiebung, Zeitschrift für vergleichende Sprachforschung auf dem Gebiete der Indogermanischen Sprachen 23(2), s. 97-130. 
